\title{
Summary
}

Methods of classifying migration, expressed in the traditional forms of migration policy of states, have been formed over a long period and are losing their former research weight, giving way to transnational dimensions.

Given the urgency of this issue, the authors of the article attempt to systematize the existing experience of typing migration and to offer a unified approach to the use of a specific typology to provide legal protection for this category of population.

Keywords: migration, typology, systematization, criterion, protection, rights and freedoms.

UDC 342.95

DOI: $10.31733 / 2078-3566-2019-5-122-127$

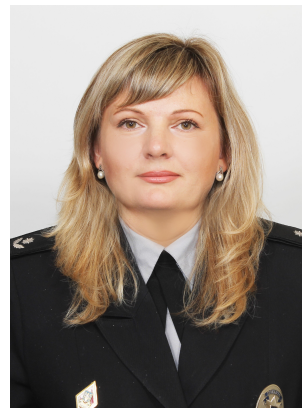

Svitlana RYZHKOVA ${ }^{\circledR}$

inspector

(the Main Department of the National Police

in Dnipropetrovsk region)

\section{STATE MIGRATION SERVICE OF UKRAINE AS AN ACTOR OF ANTI-ILLEGAL MIGRATION}

Світлана РИжкова. ДЕРЖАВНА МІГРАЦІЙНА СЛУЖБА ЯК СУБ’ЄКТ ПРОТИДІї

НЕЛЕГАЛЬНІЙ МІГРАЦІЇ. У статті розглянуто організаційно-правові аспекти діяльності Державної міграційної служби як суб'єкта протидії нелегальній міграції, та визначено основні чинники, які гальмують даний напрям. Також надані пропозиції щодо удосконалення такої діяльності.

Наголошується, що незаконна (нелегальна) міграція є одним 3 явищ, що сформувалася за часів розбудови незалежної України та становить загрозу суспільній і національній безпеці, економічній стабільності, спричинює ускладнення криміногенної ситуації на території України i серйозно впливає на стан економіки та законності. Чинником, що завжди супроводжує нелегальну міграцію, є вчинення іноземцями та особами без громадянства адміністративних правопорушень на території держави їх перебування.

Приділяється увага питанням протидії нелегальної міграції, вивченням правового регулювання суспільних відносин у сфері міграції, визначенням причин і наслідків, та способів запобігання нелегальній міграції. Також означені сучасні аспекти протидії нелегальній міграції органами державної міграційної служби в контексті міграційних ризиків, законодавчих та організаційно-правових змін в Державної міграційної служби.

Вказується, що Державна міграційна служба відповідно до покладених на неї завдань здійснює заходи щодо запобігання та протидії нелегальній (незаконній) міграції, іншим порушенням міграційного законодавства, виконує в межах повноважень, передбачених законом, правозастосовні і правоохоронні функції.

В процесі дослідження аргументується твердження про те, що незаконне перебування іноземців в Україні перетворилося на вагомий дестабілізуючий фактор у сфері забезпечення публічного порядку та безпеки. Саме 3 незаконною міграцією пов'язується зростання окремих видів правопорушень на території України.

Констатується, що відсутність інформаційної бази даних про іноземців, визнаних нелегальними мігрантами, збільшує терміни їх ідентифікації i унеможливлює оперативне здійснення працівникам територіальних органів і установ Державної міграційної служби перевірки затриманих осіб щодо повторності вчинення ними правопорушень, застосування підвищених розмірів адміністративних штрафів або інших заходів міграційного впливу.

Ключові слова: державна міграчійна служба, нелегальна міграція, мігрант, іноземеиь, особа без громадянства.

Problem statement. Ukraine is a full member of the international community on the international stage. At the same time, with the years of independence, processes related to the establishment of good neighborly relations with neighboring states, integration and strategic partnership have become increasingly important. Thus, one of the key vectors in the foreign policy of our country is the direction for the integration of Ukraine into the European Union, other interna-

(C) Ryzhkova S., 2019

ORCID iD: https://orcid.org/0000-0002-5044-6866

revord@gmail.com 
tional organizations and alliances uniting the leading democratic states of the world.

One of the conditions for the development of Ukraine as a legal state at the present stage is to identify the key directions of its migration policy and to improve the system of state regulation in the field of migration, which should be in accordance with international standards for the full protection and promotion of human rights and freedoms.

According to the Strategy of development of the system of the Ministry of Internal Affairs of Ukraine until 2020, in addition to other tasks for ensuring the formulation of state poli$\mathrm{cy}$, it is to solve problems related to migration and citizenship [1].

The main challenges identified by the Strategy are the threat to Ukraine's territorial integrity and sovereignty, the terrorist threat, the rise of transnational and organized crime and illegal migration, the smuggling of weapons, explosives and drugs, in the context of the existence of a military conflict. Illegal (illegal) migration is one of the phenomena that has emerged since the establishment of an independent Ukraine, which threatens public and national security, economic stability, complicates the crime situation in Ukraine and seriously affects the state of the economy and the rule of law. The phenomenon that always accompanies illegal migration is the committing of administrative offenses by foreigners and stateless persons in the territory of their country of residence.

Analysis of publications that started solving this problem. The problem of counteracting illegal migration, studying the legal regulation of social relations in the sphere of migration, determining the causes and consequences, and ways of preventing illegal migration at different times were explored in their works by domestic scientists - O. Bandurka, O. Malinovskaya, T. Minka, N. Tyndyk, T. Prudnikova, V. Zavoloka, M. Kuts, A. Mozol, T. Zvyozdna, O. Nagyon, V. Novik, A. Chernyak, V. Shakun, M. Shulga. However, the contemporary aspects of counteracting illegal migration by the State Migration Service bodies in the context of migration risks, legislative and organizational changes in the State Migration Service remain unexplored.

The article's objective is to study the organizational and legal aspects of the State Migration Service's activity as an actor of combating illegal migration, and to identify the main factors that hinder this area and to provide suggestions for improvement of such activity.

Basic content. According to the Regulations on the State Migration Service (hereinafter - SMS), among the main tasks of SMS is the implementation of state policy in the areas of migration (immigration and emigration), including combating illegal migration, citizenship, registration of individuals, refugees and refugees legislation of categories of migrants, takes measures to prevent and counter illegal migration, other violations of migration legislation; performs law enforcement functions within the powers provided for by law; provides for the functioning of the refugee temporary accommodation centers (hereinafter - RTAC) and the temporary accommodation centers for foreigners and stateless persons who are illegally staying in Ukraine (hereinafter - TACF); provides administrative services in accordance with the law; exercise other powers defined by law [2].

The SMS exercises its powers directly and through established territorial bodies and territorial units, including interregional organizations. The SMS is composed of the apparatus of the Service and territorial bodies (Central interregional directorates of the SMS, 24 main departments of the SMS in the regions) it includes administrations, departments (sectors) of the migration service in districts, districts in cities, cities of regional importance (total 583 territorial divisions). The management of the SMS is the Volyn and Chernihiv TACF, the State Institution "Mykolaiv TACF ", the RTAC in the Transcarpathian region, the TACF in the city of Yahotyn of the Kyiv region, the State Enterprise "the TACF in the city of Odessa" (a total of 7 institutions) and the State Enterprise "Document" (hereinafter - SE "Document") [3].

The areas of development of SMS are also covered in other strategic planning documents. In particular, the National Security Strategy of Ukraine, approved by Presidential Decree No 287 of May 26, 2015, stipulates that the development of SMS should be aimed at ensuring the rights and freedoms of citizens, providing quality administrative services, effective control over migration processes, combating illegal migration, protecting national labor market, promoting the introduction of a visa-free regime with the European Union [4].

The Decree of the Cabinet of Ministers of Ukraine No. 482-p of 12.07.2017 approved the Strategy of the state migration policy of Ukraine for the period up to 2025 (hereinafter - the Strategy). The aim of the Strategy is to direct the efforts of the state and society to formulate and implement the state migration policy, which would positively influence the consolidation of the Ukrainian nation and the security of the state, accelerate the socio-economic development, contribute to slowing down the rate of depopulation, stabilization of the quantitative and qualitative composition of the population, labor force, in line with the international standards 
and international obligations of Ukraine [5].

In accordance with its tasks, the SMS carries out measures to prevent and counter illegal (illegal) migration, other violations of migration legislation, performs law enforcement and law enforcement functions (subparagraphs 31, 38 of paragraph 4 of Regulation \# 360) [subparagraphs 31, 38] .

The Department for Foreigners and Stateless Persons is the structural unit of the SMS which implements and coordinates measures to prevent and combat illegal (illegal) migration, another violation of migration law.

According to paragraph 2 of the Regulation on the Department for Foreigners and Stateless Persons, approved by the Decree of the SMS No. 90 of 10.05.2016, its main tasks are, in particular, to: develop and take measures to implement state policy in the field of migration (immigration), the counteraction to illegal (illegal) migration, refugees and other categories of migrants defined by law; ensuring the organization, coordination and control of the activities of the RTAC, the TACF; organization and analysis of proceedings conducted in territorial bodies and SJC units in cases of administrative offenses committed by foreigners and stateless persons and, according to the requirements of the legislation, are within the competence of the SJC; control within the competence of the territorial bodies and divisions of the SMS on the powers exercised in cases of administrative offenses committed by foreigners and stateless persons, and in accordance with the requirements of the legislation, are within the competence of the SMS.

The task of preventing and combating illegal migration is entrusted to the Department for Foreigners and Stateless Persons of the SMS, departments and sectors of the organization of preventing illegal migration, readmission and expulsion of main departments (departments) of the SMS in the regions (total 30 structural subdivisions6 units). In the same field, RTACs and TACFs are also involved, with a total staffing of 417 units [2].

In view of the above, there is a multilevel migration management system in the LCA, which, in particular, counteracts illegal migration by taking appropriate measures.

In 2018 - the first six months of 2019, among 16984 illegal migrants, only 1096 persons (6.5\%) entered the territory of Ukraine illegally (without identity documents or outside checkpoints), 15888 persons (93.5\%). ) entered Ukraine legally (through checkpoints), and then went on to an illegal position [6]

The illegal stay of foreigners in Ukraine has become a significant destabilizing factor in the area of public order and security. It is illegal migration that is associated with the growth of certain types of offenses, the spread of dangerous diseases, the development of an underground labor market throughout Ukraine. Thus, according to the statistics of the SMS of Ukraine, for 2018 according to Art. 200-206 of the Code of Ukraine on Administrative Offenses in the Field of Violation of Migration Legislation of Ukraine 32930 persons were brought to administrative responsibility. (Among these indicators, the most prosecuted in part 1 of Article 203 of the Code of Administrative Offenses - 26154 persons). During 2018, the SMS of Ukraine jointly with the bodies of the State Border Guard Service, the National Police and the Security Service of Ukraine organized and carried out targeted preventive measures "Migrant", during which 5,554 illegal migrants were identified, a decision was made on forced return against 5114 persons, and forced forcibly 420, 347 foreigners were placed in TACF, 1358 foreigners were forbidden to enter Ukraine [7]. In summarizing the results and results of the preventive testing of Migrants for 2018, it was emphasized that the mass influx of illegal migrants is critical for our country and will soon pose a threat to national security [8].

The Director of the Department for Foreigners and Stateless Persons of the SMS says that the trend of illegal migration to Ukraine has no predictable decrease [8].

It should be noted that as of January 1, 2019, the number of foreigners and stateless persons recognized as refugees in Ukraine is 1,799 . The number of foreigners and stateless persons in need of additional protection in Ukraine is 768 [9]. In addition, there is a negative trend of committing criminal and administrative offenses of a general nature committed by foreigners in the territory of Ukraine, namely, in the first nine months of 2018, foreign nationals committed more than 2000 criminal offenses and over 50 thousand administrative offenses in our country, more than 1.3 Thousands of materials from this number of administrative offenses have been compiled for driving intoxicated vehicles [10]. The negative impact of the situation on illegal migration may in the near future complicate Europe's desire to strengthen its migration policy. There is a tendency towards the desire of illegal migrants to enter the EU through Ukraine, which in turn will lead to a real influx of illegal migrants and the corresponding negative consequences. Those illegals who do not reach Europe (most will be) may remain in Ukraine. In this case, the situation in the country will only get worse - the problem of illegal 
migrants may be added to the spread of crime, unemployment and total poverty [11]. These migration risks in the country require a comprehensive and well-defined organizational and legal approach, which is envisaged by the Strategy of development of the system of the Ministry of Internal Affairs of Ukraine until 2020. The leading role in this issue belongs to the State Migration Service of the Ministry of Internal Affairs of Ukraine (hereinafter - the SMS), as a subject of combating illegal migration. After all, the implementation of the proper legislative consolidation of the directions of state migration policy of Ukraine, the principles of activity of authorized entities in the field of migration largely depends on the effectiveness of counteracting the phenomena that threaten the national security of Ukraine, in particular illegal migration.

However, in spite of the positive dynamics of anti-illegal migration by the SMS, issues related to the identification of a person and the documentation of identified illegal migrants to ensure their forced expulsion outside Ukraine are an urgent problem.

Thus, in 2018, 1281 persons were placed in the TACF, of which 600 were identified (SMSs - 386, State Border Guard Bodies - 214). In the first half of 2019, 320 out of 900 people placed in TACF were identified (by the SMS - 207, by the State Border Guard - 113), or almost a third. The lowest in the Chernihiv TACF, where as of 01/01/2019 out of 182 people identified were 47, or every fourth person.

The main factors that adversely affect the above processes are the absence of an accredited diplomatic mission or consular post in the country of origin of the foreigner in Ukraine, long waiting times for replies from the competent authorities of the foreign country of origin or consular service of the Ministry of Foreign Affairs, etc., as well as inconsistencies of the SMS territorial authorities which forced expulsion of illegal migrants (sending individual requests to the foreigner's country of origin, obtaining additional information on contacting the MFA or consular offices in other countries).

In turn, a negative trend is being created that, due to untimely identification, foreigners are not expelled from Ukraine. Long-term detention of foreigners and stateless persons in TACF not only results in unproductive spending of budgetary funds, but in some cases leads to violation of the rights and freedoms of detained persons.

In total, in 2018 - the first half of 2019, 1405 foreigners and stateless persons were released from the TACF, of which 737 were forcibly expelled from the Ukraine, 79 were forcibly remitted or transferred in readmission, 276 were released on the basis of court decisions, $282-$ on termination of detention, 23 - on termination of administrative detention, and 8 on other grounds (custody, death, and unauthorized leaving of the territory).

Thus, among 1405 persons dismissed from the TACF, only 816 (58.1 percent) left Ukraine, and 589 (almost 40 percent) were released due to the expiration of their term of detention or based on court decisions. . This, in turn, creates a vicious circle that destabilizes the situation in the country and increases its risks.

Accelerated identification of illegal migrants should have been facilitated by the proper functioning of the Unified Information and Analytical System of Migration Management (hereinafter UIASMM), namely the building of an automated database in the subsystem "Aliens. Refugees", to which the employees of the territorial bodies and institutions of the SMS were to be granted access.

However, the procedure for filling out the UIASMM with data on foreigners and stateless persons, placed in the TACF, has not been developed, and the employees of the SMS do not have access to the database of the subsystem "Aliens. Refugees".

Thus, the Chernihiv PTPI has introduced an internal electronic record of foreigners and stateless persons, to which the employees of territorial bodies of LCA do not have access. Information about foreigners in electronic form by other PTPI was not collected at all [6].

According to paragraph 2.10 of the Regulations on the Department of Organization for Prevention of Illegal Migration, Readmission and Elimination of the Department, one of the main tasks of the Department is to create, administrate and maintain a database of foreigners and stateless persons who are recognized as illegal migrants and forbidden to enter Ukraine, Ukrainian individuals who contributed to their violation of migration law. However, in the absence of the necessary software, the department does not accomplish this task.

Absence of information database on aliens recognized as illegal migrants increases the terms of their identification and makes it impossible for the SMS employees of territorial bodies to check detainees on a repeated basis for repeated offenses, use of increased amounts of administrative fines or other penalties or other measures forced expulsion, transfer in readmission, etc.).

Conclusion. Therefore, it should be noted that the organizational and legal support of the State Migration Service of Ukraine as a whole allows it to perform its basic functions. 
However, in order to counteract illegal migration, it must develop and implement additional tools, first of all algorithmic and information-technical ones, in order to overcome the main factors that hinder this area of work.

\section{References}

1. Стратегія розвитку системи Міністерства внутрішніх справ України до 2020 року. URL:https:// https://mvs.gov.ua/ua/pages/strategiya 2020.htm.

2. Про затвердження Положення про Державну міграційну службу України: Постанова Кабінету міністрів України від 20 серпня 2014 p. № 360. URL:https://zakon.rada.gov.ua/laws/show/360-2014. kontakti.html.

3. Державна міграційна служба України. URL:https:// dmsu.gov.ua/pro-dms/struktura-ta-

4. Про Стратегію національної безпеки України: указ президента України від 26 травня 2015 p. № 287. URL:https://www.president.gov.ua/documents/2872015-19070

5. Про схвалення Стратегії державної міграційної політики України на період до 2025 року від 12 липня 2017 р. № 482p URL:https:// zakon.rada.gov.ua/laws/show/en/482-2017-p.

6. Звіт про результати аудиту ефективності використання бюджетних коштів, виділених Державній міграційній службі України на забезпечення виконання завдань у сферах міграції, громадянства, реєстрації фізичних осіб, біженців та інших визначених законодавством категорій мігрантів. URL:https:// rp.gov.ua/PressCenter/News/?id=150.

7. Соколюк М. Публічний звіт Голови Державної міграційної служби за результатами діяльності у 2018 році. URL:https:// https://www.kmu.gov.ua/storage/app/media/17-civik2018/zvit_2018/zvit_DMS_2018.pdf.

8. Яровий C. Проблема нелегальній міграції загрожує державній безпеці. URL:https://dmsu.gov.ua/news/dms/sergij-yarovij-problema-nelegalnoj-migraczij.

9. Державна міграційна служба: статистика 3 основної діяльності. URL:https://dmsu.gov.ua/diyalnist/statistichni-dani.html.

10. Аброськін В. Іноземці в Україні скоїли понад 52 тисячі правопорушень 3 початку року. URL: https://www.ukrinform.ua/rubric-society/2563197-inozemci-v-ukraini-skoili-ponad-52-tisacipravoporusen-zpocatku-roku-abroskin.html.

11. Погіршення міграційного клімату в Україні може загострюватися через суперечності між Трампом і Меркель. URL: https://ua.112.ua/polityka/pohirshennia-mihratsiinoho-klimatu-v-ukrainimozhezahostriuvatysia-cherez-superechnosti-mizh-trampom-i-merkel-ekspert-454.

Received to editorial office 12.12.2019

1. Stratehiya rozvytku systemy Ministerstva vnutrishnikh sprav Ukrayiny do 2020 roku [Strategy for the development of the system of the Ministry of Internal Affairs of Ukraine until 2020]. URL:https:// https://mvs.gov.ua/ua/pages/strategiya_2020.htm. [In Ukr.]

2. Pro zatverdzhennya Polozhennya pro Derzhavnu mihratsiynu sluzhbu Ukrayiny [On approval of the Regulation on the State Migration Service of Ukraine]: Postanova Kabinetu ministriv Ukrayiny vid 20 serpnya 2014 r. № 360. URL:https://zakon.rada.gov.ua/laws/show/360-2014. [In Ukr.]

3. Derzhavna mihratsiyna sluzhba Ukrayiny [State Migration Service of Ukraine]. URL: https:// dmsu.gov.ua/pro-dms/struktura-ta-kontakti.html. [In Ukr.]

4. Pro Stratehiyu natsional'noyi bezpeky Ukrayiny [On the National Security Strategy of Ukraine]: ukaz prezydenta Ukrayiny vid 26 travnya 2015 r. № 287. URL:https://www.president.gov.ua/documents/2872015-19070. [In Ukr.]

5. Pro skhvalennya Stratehiyi derzhavnoyi mihratsiynoyi polityky Ukrayiny na period do 2025 roku [On approval of the State Migration Policy Strategy of Ukraine for the period up to 2025] vid 12 lypnya 2017 r. № 482r URL:https:// zakon.rada.gov.ua/laws/show/en/482-2017-r. [In Ukr.]

6. Zvit pro rezul'taty audytu efektyvnosti vykorystannya byudzhetnykh koshtiv, vydilenykh Derzhavniy mihratsiyniy sluzhbi Ukrayiny na zabezpechennya vykonannya zavdan' u sferakh mihratsiyi, hromadyanstva, reyestratsiyi fizychnykh osib, bizhentsiv ta inshykh vyznachenykh zakonodavstvom katehoriy mihrantiv [Report on the results of the audit of the effectiveness of the use of budgetary funds allocated to the State Migration Service of Ukraine to ensure the fulfillment of tasks in the areas of migration, citizenship, registration of individuals, refugees and other categories of migrants defined by law]. URL:https:// rp.gov.ua/PressCenter/News/?id=150. [In Ukr.]

7. Sokolyuk, M. Publichnyy zvit Holovy Derzhavnoyi mihratsiynoyi sluzhby za rezul'tatamy diyal'nosti u 2018 rotsi [Report on the results of the audit of the effectiveness of the use of budgetary funds allocated to the State Migration Service of Ukraine to ensure the fulfillment of tasks in the areas of migration, citizenship, registration of individuals, refugees and other categories of migrants defined by law]. URL : https:// https://www.kmu.gov.ua/storage/app/media/17-civik-2018/zvit 2018/zvit DMS 2018.pdf. [In Ukr.]

8. Yarovyy, S. Problema nelehal'niy mihratsiyi zahrozhuye derzhavniy bezpetsi [The problem of illegal migration threatens state security]. URL:https:/dmsu.gov.ua/news/dms/sergij-yarovij-problemanelegalnoj-migraczij. [In Ukr.]

9. Derzhavna mihratsiyna sluzhba: statystyka z osnovnoyi diyal'nosti [State Migration Service: statistics on main activity]. URL : https://dmsu.gov.ua/diyalnist/statistichni-dani.html. [In Ukr.]

10. Abros'kin, V. Inozemtsi v Ukrayini skoyily ponad 52 tysyachi pravoporushen' $\mathrm{z}$ pochatku roku [Foreigners in Ukraine have committed more than 52 thousand offenses since the beginning of the 
year]. URL : https://www.ukrinform.ua/rubric-society/2563197-inozemci-v-ukraini-skoili-ponad-52tisaci-pravoporusen-zpocatku-roku-abroskin.html. [In Ukr.]

11. Pohirshennya mihratsiynoho klimatu v Ukrayini mozhe zahostryuvatysya cherez superechnosti mizh Trampom i Merkel' [The deterioration of the migration climate in Ukraine may be exacerbated by the controversy between Trump and Merkel]. URL: https://ua.112.ua/polityka/pohirshenniamihratsiinoho-klimatu-v-ukraini-mozhezahostriuvatysia-cherez-superechnosti-mizh-trampom-i-merkelekspert-454. [In Ukr.]

\section{Summary}

The article deals with the organizational and legal aspects of the activity of the State Migration Service as a subject of combating illegal migration, and identifies the main factors that hinder this area. Suggestions for improving such activities were also provided.

Keywords: state migration service, illegal migration, migrant, foreigner, stateless person.

UDC 342.95

DOI 10.31733/2078-3566-2019-5-127-133

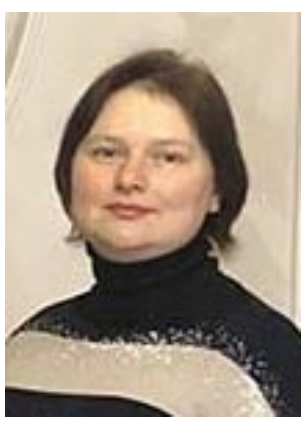

Liliya TIMCHENKO ${ }^{\odot}$

Lecturer

(Dnipropetrovsk State University of Internal Affairs)

\section{EUROPEAN INTEGRATION DIRECTIONS TO IMPROVE THE SYSTEM OF PROVIDING ADMINISTRATIVE SERVICES}

ЛіЛіЯ ТИМЧеНКО. ЄВРОІНТЕГРАЦІЙНІ НАПРЯМИ УДОСКОНАЛЕННЯ СИСТЕМИ

НАДАННЯ АДМІНІСТРАТИВНИХ ПОСЛУГ. СтатТя присвячено аналізу законодавства Європейського Союзу щодо забезпечення якісних, доступних, професійних послуг органів влади населенню цих країн. Автор зазначає, що сектор послуг $є$ настільки важливим в Європейському Союзі, що їх належне забезпечення регулюється первинним і вторинним законодавством, зокрема статями Договору про заснування Свропейського Союзу та Договору про функціонування Європейського Союзу, окремого Протоколу до нього, а також кількома Директивами, прецедентним правом, Хартією засадничих прав Європейського Союзу.

Значну роль у регулюванні сфери послуг відіграв Суд $\mathrm{CC}$, який кілька разів виносив рішення по послугах загальноекономічного інтересу. Рішення Суду ЄС забезпечують основу для визначення загальноекономічного інтересу на національному рівні. Однак кожне рішення досягається на індивідуальній основі, з урахуванням умов і національних особливостей державчленів. Автор звертає увагу, що 6 вересня 2001 р. Свропейський Парламент схвалив резолюцію про затвердження Європейського кодексу належної адміністративної поведінки. Зазначений документ, ухвалений з певними змінами на основі проекту Омбудсмана СС, хоча і не $\epsilon$ формально обов'язковим, проте користується значною повагою і авторитетом. Він справив значний вплив на законодавство і практику публічної служби в країнах СС, а також став основою прийняття етичних кодексів поведінки службовців окремих інституцій Союзу.

Основні принципи надання адміністративних послуг у країнах ЄС лягли у основу законодавчого каркасу взаємодії органів місцевої влади та населення й забезпечили вектори відносин у сфері надання таких послуг, які мають специфічні правові форми діяльності місцевої влади. Автор робить висновок, що у значній кількості країн $\mathrm{CC} \mathrm{та} \mathrm{у} \mathrm{Великій} \mathrm{Британії}$ адміністративні послуги надаються в основному органами місцевого самоврядування. У той же час ключовим механізмом стимулювання підвищення якості надання адміністративних послуг населенню виступає диверсифікована система незалежної оцінки якості таких послуг, що необхідно впровадити й в Україні.

Ключові слова: публічні, адміністративні, мунічипальні та державні послуги; державне управління; органи державної влади; органи місиевого самоврядування.

Problem statement. The social policy of the state is based on the communication of the state authorities and the population in order to ensure decent social standards in the country. This policy is quite diverse, but the key role in public administration is played by the provision

(C) Timchenko L., 2019

https://orcid.org/0000-0003-2696-0272

k_cpd@dduvs.in.ua 